\title{
legelivet
}

På disse sidene i Tidsskriftet - legelivet - finner du stoff om legers liv.

Her er det presentasjon av arbeidssteder, nyhetssaker, nye doktorgrader,

nye spesialister, prisutdelinger og minneord.

Alt samlet på ett sted - så du kan følge enda bedre med.

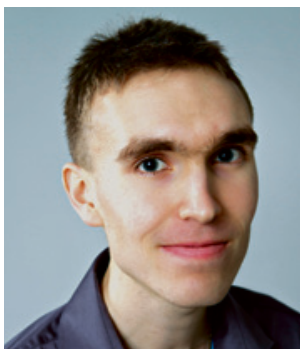

Frederik Emil Juul. Foto: Einar Nilsen

Frederik Emil Juul (f. 1989) er medisinstudent ved Universitetet i Oslo og redaktør i medisinstudentmagasinet AEsculap

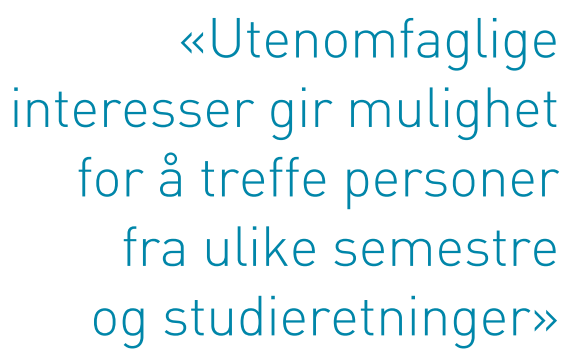

og studieretninger»

\section{Hva liker du å gjøre?}

\section{Studietiden bør dreie seg om mer enn studier. Fritidsaktiviteter kan gi} både overskudd og trygghet i vanskeligere perioder.

All begynnelse kan være spennende og litt skremmende. For medisinstudenter kan det være snakk om starten på studietilværelsen, eller nok et semester med helt nytt innhold. Universitetsstudiet betyr for mange flytting hjemmefra, kanskje til en ny by. Det gir ofte nye hverdagsutfordringer i form av endret klima, redusert kontakt med nære venner eller ukjente gjøremål som å ta egen klesvask.

Studiene tar mye tid, men det kan være fint å fylle hverdagen også med andre hendelser enn timer på lesesalen, forelesninger og legefotfølging. Å kalle det en hobby eller fritidsaktivitet kan virke litt gammelmodig, men er likevel treffende. Om det er deltakelse i en sjakkgruppe, humanitær studentorganisasjon eller maling, spiller ingen rolle, så lenge det er noe du liker å gjøre. En studentgruppe kan fungere som en energigivende arena der tankene beveger seg bort fra en eksamen som nærmer seg.

Personlig mener jeg det viktigste er at et slikt studentengasjement er et engasjement, at du bruker overskuddet - eller aller helst får overskudd - av det du har engasjert deg i. Oppleves det som en ekstrajobb, blir aktiviteten raskt til skade mer enn nytte.

Det finnes organisasjoner og grupperinger for det meste, og skulle det være et tilbudshull, kan du kanskje ta initiativet til å tette det? Aktiviteten trenger ikke å være sofistikert eller akademisk, ha et mål om å utrydde tuberkulose eller å vinne Birkebeineren. I Trondheim var en gruppe studenter så glad i brettspillet «Den forsvunne diamant» at de ukentlig samlet seg for å spille. En felles interesse brakte likesinnede sammen. Dessuten: Slike utenomfaglige interesser gir mulighet for å treffe personer fra ulike semestre og studieretninger, ikke bare medstudenter på eget medisinkull.

Forhåpentligvis kommer både gamle og nye fjes til høstens studentaktiviteter, uavhengig av innholdet. Kanskje har ferien gitt rot til ideer om nyetableringer eller endringer av eksisterende studentgrupper. Jeg gleder meg, for studentengasjement er gøy! 